\title{
Chitradurga: Spatial Patterns of a Nayaka Period Successor State in South India
}

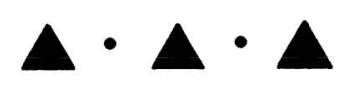

BARRY LEWIS AND C. S. PATIL

The NAYAKa PERIOd IN SOUTh INDIAN HISTORY spans the centuries between the collapse of the Vijayanagara empire in the late sixteenth century and the consolidation of British power in the south at the beginning of the nineteenth century. It was an era of dynamic social change, during which petty rulers and subsidiary chiefs, known variously in the literature as "little kings," nayakas, ${ }^{1}$ and poligars (hereinafter referred to collectively as "poligars" for the sake of convenience), acquired and expanded territories, claimed increased status and legitimacy, and often asserted their independence of higher ruling authority (Chitnis 1974, 2000; Dirks 1994; Dua 1996; Rajayyan 1974; Stein 1985). A few of these kingdoms, notably Mysore, Keladi, Madurai, Tanjore, and Gingee, were eminently successful and their histories dominate our understanding of the period (e.g., Aiyar 1991; Brittlebank 1997; Chitnis 1974; Deloche 2000; Dirks 1982, 1994; Michell 1995:1-3; Narayana Rao et al. 1992; Swaminathan 1957; Vriddhagirisan 1995). Significantly less is known about the scores of smaller kingdoms and chiefdoms that populated the Nayaka period landscape (Ramachandra Rao 1943).

Our objective is to describe an archaeological and ethnohistorical case study of Chitradurga, which was one of the important Nayaka polities of central Karnataka (Fig. 1). Between A.D. 1500 and 1800, Chitradurga was at various times a Vijayanagara province, an independent kingdom, a tributary of the Marathas, a tributary of the Mughals, a tributary of Mysore, and, finally, a Mysore province. It also was often at war with most of its neighbors. In spite of its tumultuous recent past, Nayaka period Chitradurga is so little known that it warrants only a modest footnote in Karnataka archaeology.

The specific goal of this case study is to identify and interpret major spatial patterns of the Chitradurga cultural landscape as they existed in the late eighteenth and early nineteenth centuries. The data are primarily drawn from our recent archaeological surveys in the Chitradurga region (Lewis 1997; Patil 1999) and from the highly detailed manuscript maps of Mysore made by Colin Mack-

Barry Lewis is a professor in the Department of Anthropology, University of Illinois, Urbana. The late C. S. Patil was the deputy director of Karnataka Directorate of Archaeology and Museums, The Palace Complex, Mysore, India, and research associate in the Department of Anthropology, University of Illinois, Urbana.

Asian Perspectives, Vol. +2, No. 2 \& $20(0) 3$ by the University of Hawai'i Press. 


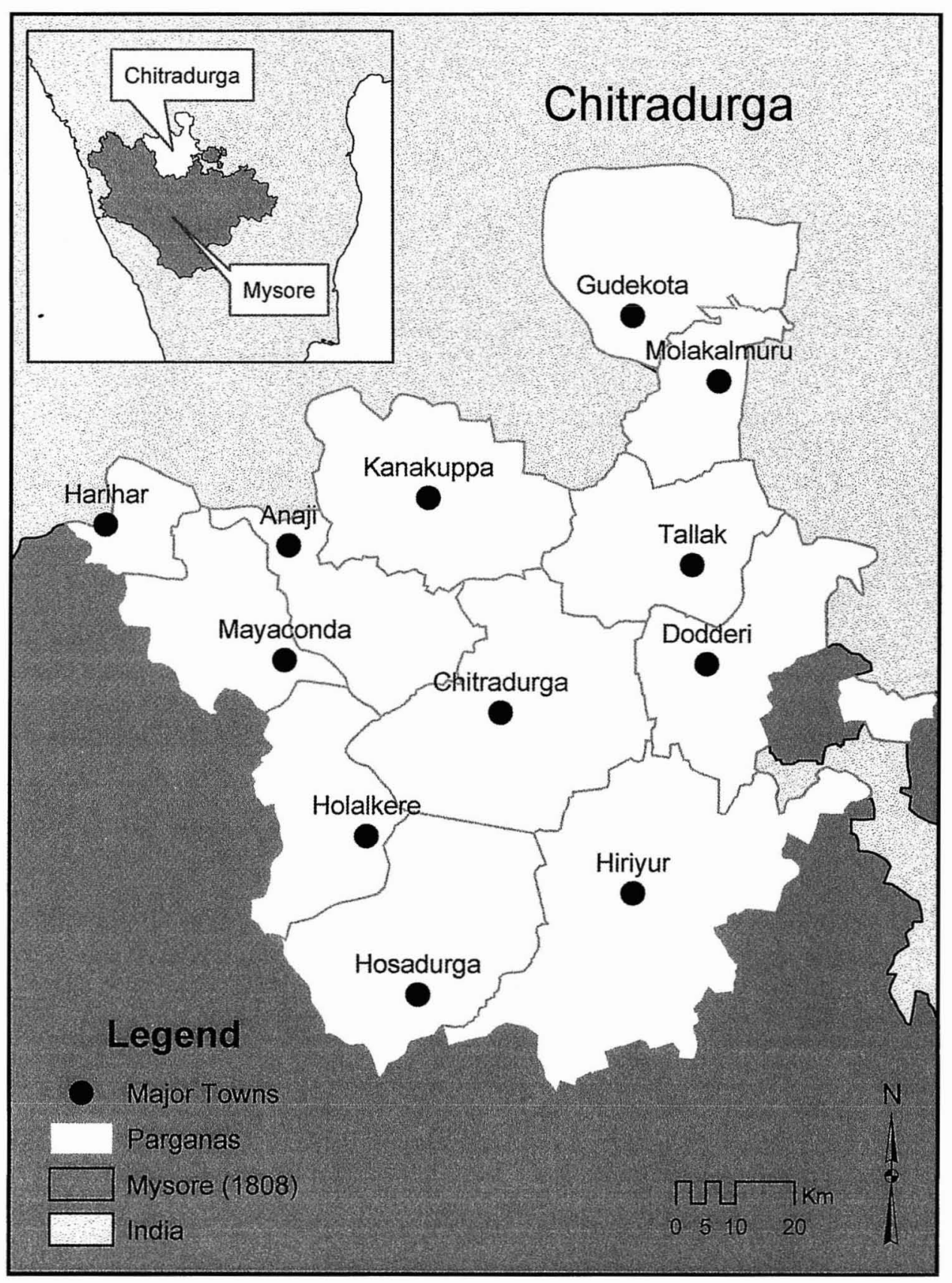

Fig. 1. Chitradurga province, showing parganas and the major towns.

enzie and his surveyors in the first decade of the 1800s (Edney 1997:175-179; Phillimore 1945-1958:2:91-121; Robb 1998). The results provide a distinctively archaeological perspective of this province, emphasize the important role that such polities played in the historical developments of the Nayaka period, and 
illustrate the significant interpretative value of early East India Company (EIC) manuscript maps for archaeological site survey and spatial analyses of early modern India. These results complement the perspective that can be gained from analyses of contemporary historical and literary texts and contribute significantly to a richer understanding of such polities than would be possible otherwise.

We begin with an overview of the recent history of Chitradurga and the data used in this study. Next, the major cultural features of the region are described as they were at the beginning of the nineteenth century. The final section identifies important spatial patterns of these features and interprets their significance in the cultural context of that time.

\section{CHITRADURGA IN HISTORICAL PERSPECTIVE}

Chitradurga was one of several central Karnataka regions governed by local chieftains well before the rise of Vijayanagara, which inherited control of the region from the Hoysalas in the early fourteenth century. By the early sixteenth century, it was controlled largely by a Bedar or Boya caste family who traced their origins to southern Andhra Pradesh from which they had emigrated with their herds (Hayavadana Rao 1930:5:1380-1387; Rice 1897:1:500-505). Like most of the central Karnataka families who rose to power in the sixteenth century (e.g., Chitnis 1974:9-14; Ota 1999), the Chitradurga poligars based the legitimacy of their status as an elite lineage on their relationship with the Vijayanagara kings, who, it is claimed, appointed several of their line as nayakas after they attracted the attention of the Vijayanagara rulers through acts of daring and bravery (Puttanna 1924; Srikantaya 1941).

After the fall of the city of Vijayanagara in 1565, the Chitradurga family and most other central Karnataka poligars soon declared their independence of the remnants of that empire. They also were in the thick of the chronic regional warfare that became one of the hallmarks of the Nayaka period. They warred repeatedly with the Basavapatna or Tarikere poligars whose country lay to the west, with the Harapanahalli poligars to the north at Uchchangidurga; with the Harati or Nidugal family at Dodderi and later at Nidugal; with the Hatti family, whose headquarters town was Nayakanhatti to the northeast; and with the Rayadurga poligars, among others (Hayavadana Rao 1930:5:1380-1387; Ota 1999; Sathyan 1967:53-61). They enjoyed moderate success in regional warfare until the mid-seventeenth century, when the Mughals invaded central Karnataka and established the suba (major province) of Sira. Although the territories of many former poligars in the region became parganas (lesser provinces) under the Mughals, Chitradurga was one of the fortunate few to enjoy limited independence as a tributary of Sira (Hayavadana Rao 1930:5:536-537).

These events did not lessen the pace of internecine warfare, which continued on the borders of Chitradurga and was increasingly directed at the Marathas, who were pressing down from the north, and, when opportunity presented itself, against the Mughals. Chitradurga's political position became untenable in the late eighteenth century after it was caught between the Marathas and Haidar Ali of Mysore in their struggle for control over central Karnataka. Haidar Ali finally succeeded in taking Chitradurga Fort ${ }^{2}$ in 1779 and the region became a Mysore province (Rice 1897:1:504; Saletore 1940; Srikanta Sastri 1928). Madakari 
Nayaka the Last, the final direct ruler of Chitradurga, and his family were imprisoned at Shrirangapattana, where they died. To break the power of the Bedar caste in the region, whose members had loyally supported the Chitradurga poligars, Haidar Ali also is said to have moved more than 20,000 Bedars from Chitradurga to Shrirangapattana, the young men of which were pressed into service in his chela battalions $^{3}$ (Bowring 1899:72-75; Wilks 1989:743).

After the fall of Shrirangapattana in early May of 1799, Chitradurga remained a province of Mysore under the Wodeyars, whom the British returned to power. Today it is one of the 27 districts of the State of Karnataka. Until the late 1990s, its poligar heritage was reflected in the boundaries of Chitradurga District, which encompassed most of the territory held by Madakari Nayaka the Last when Chitradurga Fort fell to Haidar Ali.

\section{DATA SOURCES}

Chitradurga's rich past first captured international attention in the late nineteenth century with the discovery of three Aśokan edicts at Brahmagiri, Siddapura, and Jatinga-Ramesvara in the far northeastern corner of the district (Rice 1903:91, 93, 96). Excavations at Brahmagiri and Chandravalli, the latter of which lies immediately west of Chitradurga, demonstrated early in the twentieth century that the archaeological record of this region is temporally deep, significant, and little known (Krishna 1993a:23-27, 1993b:23-33; Nagarajan and Sundara 1985; Settar 1976:99-103; Wheeler 1948:180-310). Krishna (1993a:13-14, 1993b: 27-33, 199) published brief descriptive accounts of Chitradurga Fort and other archaeological sites in this district in the early 1930s, and local historians, such as M. S. Puttanna (1924) and H. S. Jois, devoted considerable attention to Chitradurga and its poligars in the first half of the twentieth century (Srinivas 1991; Sujatha 1991).

However, since Puttanna and Jois published mostly in Kannada, their research has had little impact outside of Karnataka. Sri H. S. Jois warrants additional mention because he single-handedly created the archaeological museum housed in Rangayyana Bagilu, one of Chitradurga Fort's gateways, where it is still maintained by the Karnataka Directorate of Archaeology and Museums (KDAM).

Three main factors have inhibited archaeological research on the Nayaka period in Karnataka. First, the Nayaka period is essentially modern times in India, and, until recently, many archaeologists viewed it as lying outside the domain of archaeological enquiry. Second, archaeological reconnaissance survey coverage in South India is spotty and no agencies act as central repositories for site location information. Third, access to aerial photos and high-resolution digital imagery is constrained greatly, if not effectively prohibited, by national security concerns. The immediate consequence is that, not only do archaeologists know little about the period, they cannot readily turn to many of the kinds of data that are viewed as essential to archaeological spatial studies elsewhere.

To mitigate the effects of these problems, we began archaeological reconnaissance surveys in Chitradurga District in 1996, with emphasis on Nayaka period fortified sites (Lewis 1997; Patil 1999). The fieldwork has been augmented by archival research on eighteenth- and early nineteenth-century EIC and Indian 
records (Lewis 2000, 2001). These complementary lines of research helped to enhance our understanding of the central Karnataka poligars in at least two ways.

First, it enabled us to begin constructing a highly detailed geographic information system (GIS) model of the cultural landscape of the Mysore kingdom as it existed between 1799 and 1808, immediately after the death of Tipu Sultan. The model combines the results of modern reconnaissance surveys with information gleaned from large-scale (typically $2 \mathrm{mi}$ to the inch, or $1.27 \mathrm{~km}$ to the centimeter) unpublished EIC maps of the late eighteenth and early nineteenth centuries (Fig. 2). Analyses of this model, which is complete for Chitradurga but still under development for the rest of Mysore, facilitate the delineation of important spatial relationships and provide something that is currently unattainable by other means - a virtual archaeological site file of thousands of contemporaneous Nayaka cultural features, including towns, villages, roads, reservoirs, and their place names.

Second, it permits us to reconstruct the major features of individual forts, based on the integration of modern archaeological survey data and EIC fort inventories that report building-level construction details. The meticulous detail of the EIC fort inventories enable a comparative analysis of their overall designs, major spatial divisions, siege supply storage systems, and even identify the names and intended uses of buildings that are recognizable today only as wall stubs or archaeological features. ${ }^{4}$

The following sections report on the preliminary analysis of the major spatial patterns of the Chitradurga region. The inferences we derive from these analyses are properly viewed as working hypotheses to be examined in the field and against the results of our continuing archival research. Given the nature of the historical cartographic data that informs most of this analysis, our focus is primarily on economic and political spatial patterns.

\section{CHITRADURGA PROVINCE}

The former Chitradurga province (Fig. 1) lies in Karnataka's southern maidan region, most of which is a high plateau of gently rolling scrub jungle. A belt of hills ranges across the western half of the region in a general south to southwest trend; another major hill range crosses the northeastern part of the province. The climate is semi-arid due to the rain shadow effect of the Western Ghats, which lie between Chitradurga and the Arabian Sea. The average annual precipitation is only about $58 \mathrm{~cm}$, half of which falls during the southwestern monsoon between June and September (Sathyan 1967:22-23). Drainage is provided by the Vedavati and Tungabhadra rivers, which form part of the Krishna Basin and empty into the Bay of Bengal.

\section{Macrospatial Patterns}

To delineate the major spatial patterns of the region's cultural landscape, we first describe Chitradurga's major administrative divisions and then examine its elements. In 1800 Chitradurga was divided into 12 parganas, each of which had a centrally located major town (Fig. 1). The parganas were roughly of the size of a modern taluk (a subdivision of a district), but of somewhat greater adminis- 


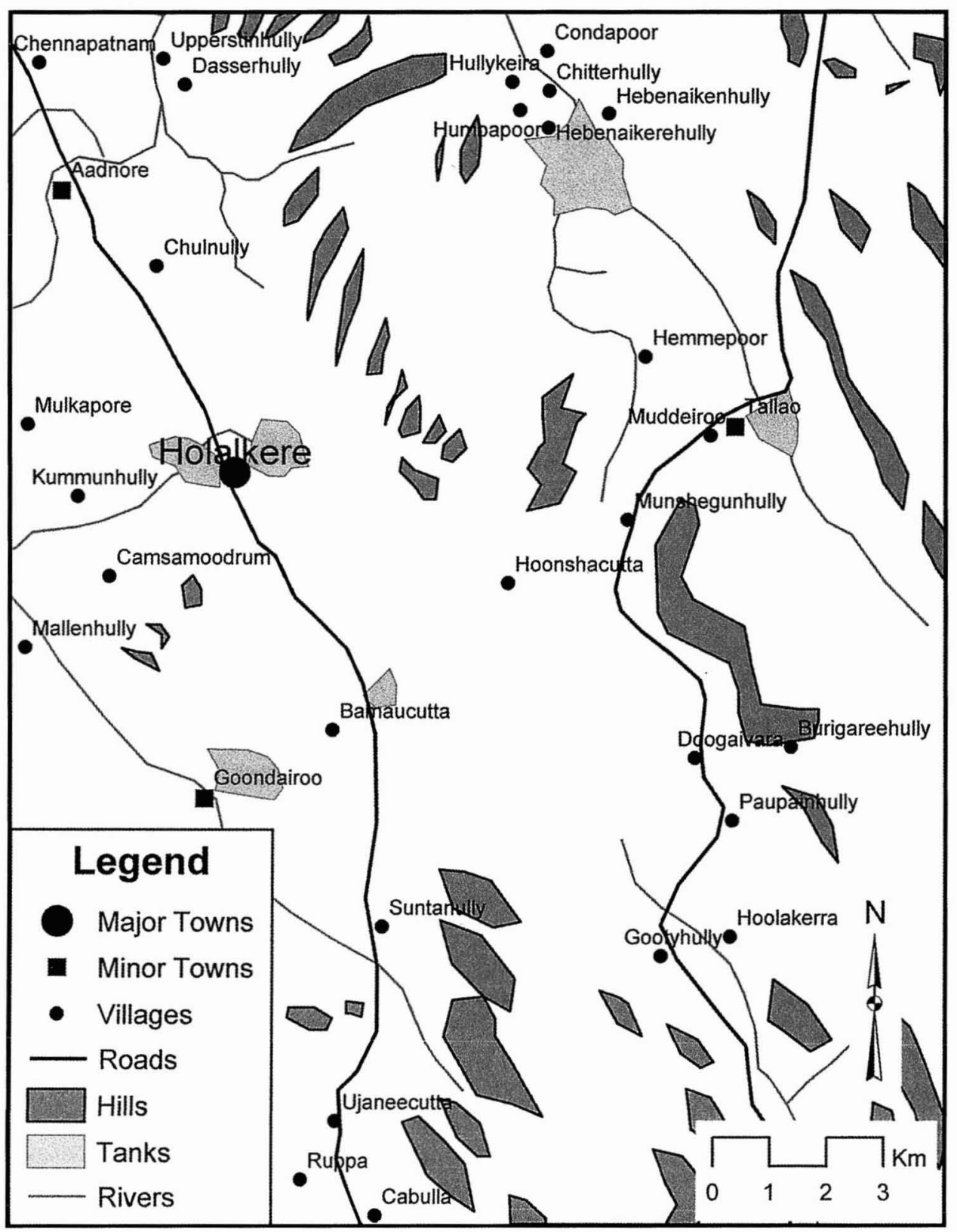

Fig. 2. Example of Mysore GIS details, showing towns, villages, roads, tanks, and major streams in the eastern part of Holalkere pargana as it existed in 1800-1801; digitized from unpublished Mysore Survey maps. However, a GIS is far more than a mere map. What this figure cannot show is that for each town, village, tank, river, road, and other feature depicted on the map, there is a corresponding database entry that contains the values for such diverse variables as annual revenue yield, the presence or absence of a defensive ditch, and stream rank order. 
trative importance. Although pargana is a Mughal administrative term (Fox 1971; Richards 1993), comparable local divisions of the landscape existed before Vijayanagara times.

Our analysis suggests that pargana boundaries were drawn on the basis of a wide range of economic and social concerns that centered on the major towns of the province. This inference is based on two lines of evidence, (1) the historical continuity of pargana boundaries, and (2) the congruence of these boundaries with Thiessen polygons ${ }^{5}$ centered on the major towns.

While there is little reason a priori to anticipate that local administrative boundaries should endure over the centuries, roughly one-third of the modern taluks of Chitradurga District follow much the same lines as the late eighteenth-century provincial parganas. The survival of these boundaries after more than 200 years of profound social, economic, and political change in South India, supports the view, for which there is considerable external evidence (e.g., Fox 1971; Gordon 1994), that changes of government have often had little impact on low-level administrative structures in India.

Why should local boundaries endure? Surprisingly, the explanation may rest more with geography than human agency. Inspection of a network of Thiessen polygons centered on the province's major towns, as they existed in 1800, shows that many, but by no means all, pargana boundaries lay roughly halfway between a given town and its neighbors (Fig. 3). The pattern is consistent with boundaries that define service areas of major towns rather than the limits of territories carved out by local elites or the organization of revenue collection (i.e., on interaction patterns based more on simple physical proximity than on fiat). If true, it further implies that there was relatively little local-level administrative authority or power concentrated in the parganas. If the boundaries of these units were primarily territorial or based on revenue yield, it is reasonable to expect that their extent would clearly reflect the relative political power of local elites and local economic factors, and not be explicable as a function of the distance that separates each town. That the latter is sufficient to explain the patterns based on the data at hand encourages us to explore this further in our archival research and archaeological surveys.

Within the province as a whole, the general settlement pattern delineated by the Mysore Survey was minimally a four-tiered hierarchy of 722 villages, 65 minor towns, 11 major towns, and the provincial capital of Chitradurga Fort. The capital and its immediate hinterland formed one of the province's 12 parganas. The other 11 major towns, all of which were well fortified and built to withstand sustained sieges, were the economic, social, and religious centers of their respective parganas. A rough grid of unpaved roads provided the primary means of communication between the 12 major towns. Seven of the province's major towns occupied nodal positions in this grid, and Chitradurga Fort lay at the intersection of no less than nine roads. Prior to 1779 , some of the parganas were governed by administrators appointed by the Chitradurga nayaka; in a few cases, however, lesser nayakas of local lineages were appointed to these posts. Under Haidar Ali and Tipu Sultan, all of the major towns were placed under the control of commanders appointed from Shrirangapattana.

Within each pargana were 3-9 minor towns, and all but three of the 65 identified minor towns were fortified. In marked contrast to the pattern described 


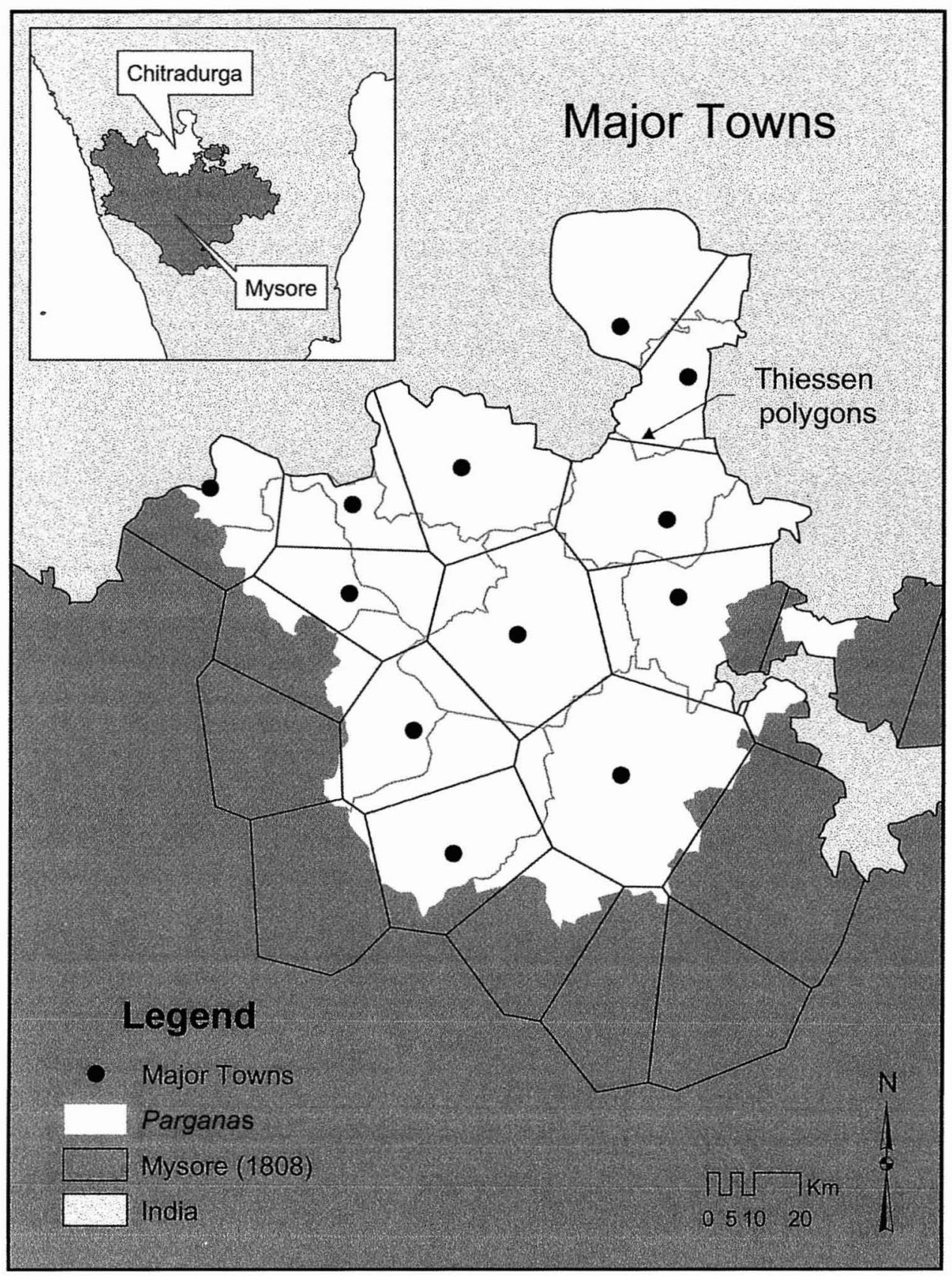

Fig. 3. Thiessen polygons based on the major towns, showing the general congruence with pargana boundaries. 
above for the major towns, Thiessen polygons centered on the minor towns show no relationship with pargana boundaries or with the boundaries of modern taluks. In other words, the distribution of minor towns does not vary with simple factors of geography. It does, however, respond to the proximity of major towns. Viewed simply as areas of influence, the polygons defined on the minor towns also are notable in that none contain more than one major town. The pattern suggests the spatial distribution of minor towns is at least partly a function of the distribution of the major towns they served, or vice-versa. Support for this inference comes from the subsequent history of the relationship between individual pairs of major and minor towns. For at least three of the 12 pairs, the late eighteenth-century minor town now over-shadows, if not completely replaces, its former nearby major town. ${ }^{6}$ No single factor accounts for the rise and fall of the regional importance of these locations.

The 1800-1801 Mysore Survey map of Chitradurga province also records 722 named villages, all of which appear to have been nucleated settlements, a typical maidan village pattern that persisted into the twentieth century (Buchanan 1807:32; Hayavadana Rao 1930:1:367). When viewed across time, it is evident that Nayaka villages differed from towns in several striking ways. First, many villages did not show the same enduring continuity of settlement that characterizes most of the towns. With few exceptions, the major and minor towns that were inhabited between 1799 and 1808 are still inhabited today. However, the villages have proved to be more ephemeral; many of the 722 villages that we have digitized from the Mysore Survey maps cannot be cross-referenced to village locations on modern Survey of India topographical maps. Second, while historical differences in town locations appear to reflect the force of political and economic changes over the intervening centuries, differences at the village level are more easily explained as a result of such basic factors as the removal of any need for village defense, new reservoirs (e.g., the 8700 ha Vanivilas Sagar Reservoir and the 1200 ha Gayatri Reservoir, both of which are in the southern half of the district), the proliferation of tubewells, the increased availability of all-weather roads, and changes in the region's agriculture (Green 1846; Hayavadana Rao 1930:3:156174; Sathyan 1967:119-120).

Roads and reservoirs exerted greater "pull" on village location choices than the small stream valleys that drain the region, largely, we suspect, because most streams were dry for much of the year, just as they are today. ${ }^{7}$ Roads provided the major communication lines and reservoirs offered consistent water supplies. Of the 65 minor towns in the province, 35 (54 percent) were located within $3 \mathrm{~km}$ of a reservoir in 1801, and 26 of these 35 minor towns were less than $1 \mathrm{~km}$ from a reservoir.

Another consistent pattern of village site distribution was to avoid all but the fringes of the hill ranges that dot the province. The notable exceptions to this generalization are isolated hills, the tops of many of which were crowned by forts, temples, or both, and were typically attended by small nearby villages.

In summary, the pargana boundaries of late eighteenth-century Chitradurga province appear to reflect the enduring nature of towns in the region and a certain level of concern for minimizing travel and transportation costs rather than power struggles between local elites or an organizational structure imposed from above. Relatively little administrative authority or power appears to have been 
held by pargana-level institutions. The provincial settlement pattern was hierarchical and sufficiently stable to be recognizable today in the modern Chitradurga landscape. Evidence of the hierarchical integration of major and minor towns can be seen in the replacement of at least three major towns by their closest minor town during the past two centuries.

\section{Microspatial Patterns}

Chitradurga Fort - Even if archaeologists lacked historical context for the region, site survey would readily demonstrate that Chitradurga Fort is a place apart (Fig. 4). Evidence of its occupation dates back for several thousand years and, before the advent of the railways in the late nineteenth century, it commanded the single most important transportation node in the region. This fortified town and hill fort was the capital of a Nayaka kingdom and, later, a favored provincial headquarters town of the Mysore sultanate. It also was an important material symbol of legitimacy in the region. Whoever held Chitradurga Fort, held the key to the province.

Among the characteristics that set it apart from the other major towns of the province were large palaces, courtly architecture, swings and other architectural trappings of kingship, the latter of which are set in areas dedicated to ritual and royal display (Fig. 5; Wagoner 2001). The combination of differing architectural traditions is particularly evident in the multiple fortification lines, where one finds French- and English-designed ramparts and parapets punctuated by prominent gateways that combine South Indian and Bahmani-derived elements. Chitradurga Fort also contains the largest and most well-endowed temples of the province, a connection that once enhanced the status and legitimacy of this town. Its status remained unchallenged from the Nayaka period until in the late 1990s, when the former minor town of Davangere had grown so much larger in population and economic influence that it became the headquarters town of a new district carved out of Chitradurga.

Although it is one of the best preserved Nayaka period forts in South India, Chitradurga Fort is archaeologically unknown except for Krishna's (1993a:14$22,50-65,199)$ brief description of its major monuments in the late 1920s and Wagoner's (2001) study of its entrance pavilions. C. S. Patil recently completed a detailed archaeological survey of this site, which will be an integral part of the Chitradurga monograph that we are now preparing for publication. Our research on Chitradurga Fort has been aided significantly by the discovery of a 240-page manuscript (Barclay 1802) that gives a wall-by-wall, building-bybuilding description of the construction, condition, and current and former use of every building, wall, gate, and tower in the fort, as well as an assessment of what steps must be taken to make the fort defensible against assault. For example, the Chitradurga Fort inventory describes the mud brick circular buildings depicted in Figure 6 as follows: "No. 31, 32, 33, 34, 35, granaries. Circular buildings, 12 feet diameter, walls mud, roof mud terrace thatched; Present State: unserviceable; Where Situated: near the upper palace" (Barclay 1802:246-247). The fort inventory manuscript, Patil's survey, and Colin Mackenzie's 1800 plan of Chitradurga Fort, enable us to reconstruct a highly detailed and accurate picture of 


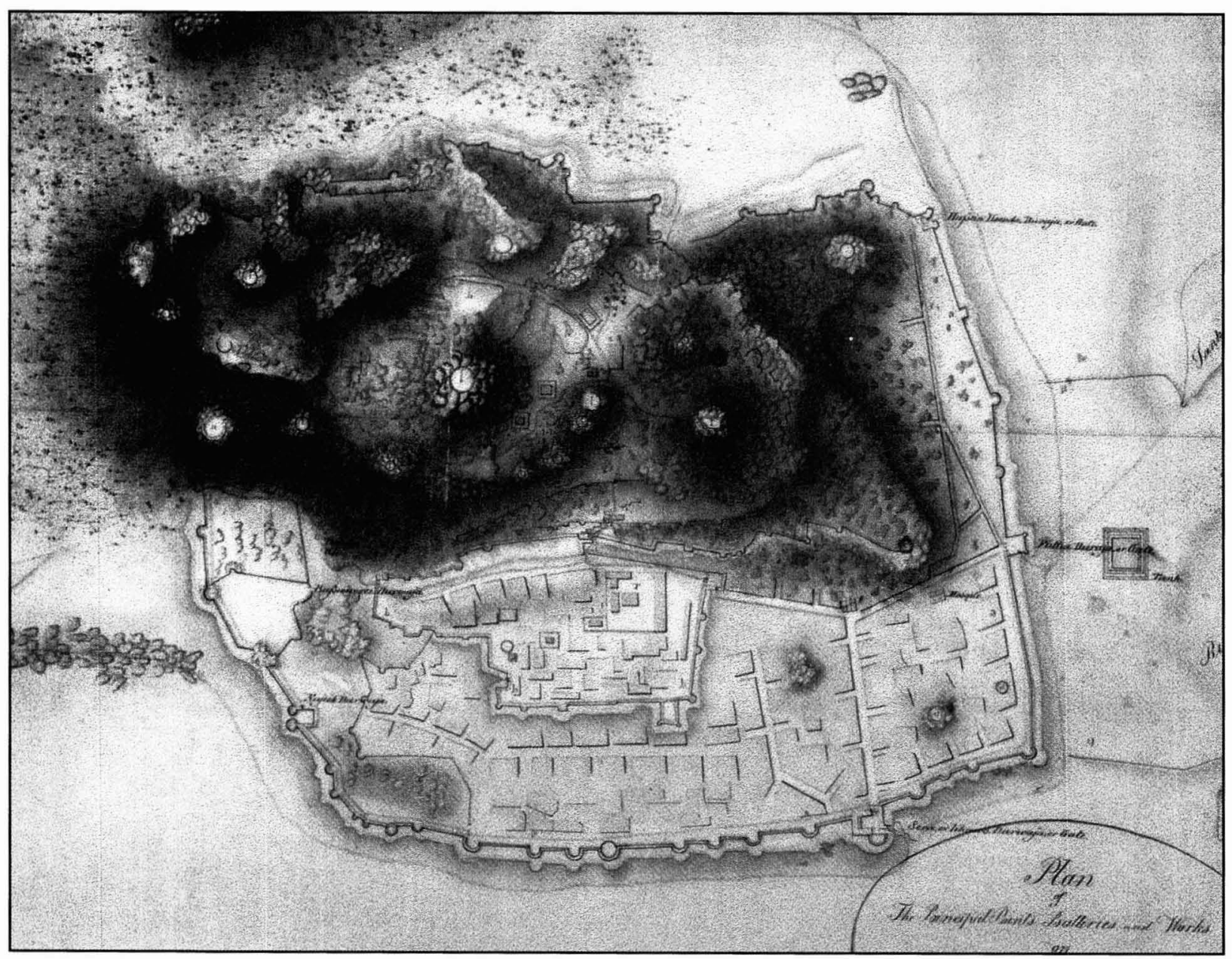

Fig. 4. Detail from a plan of Chitradurga Fort drawn by Colin Mackenzie, dated June 1800. (By permission of The British Library, IOR prints WD 2634.) 


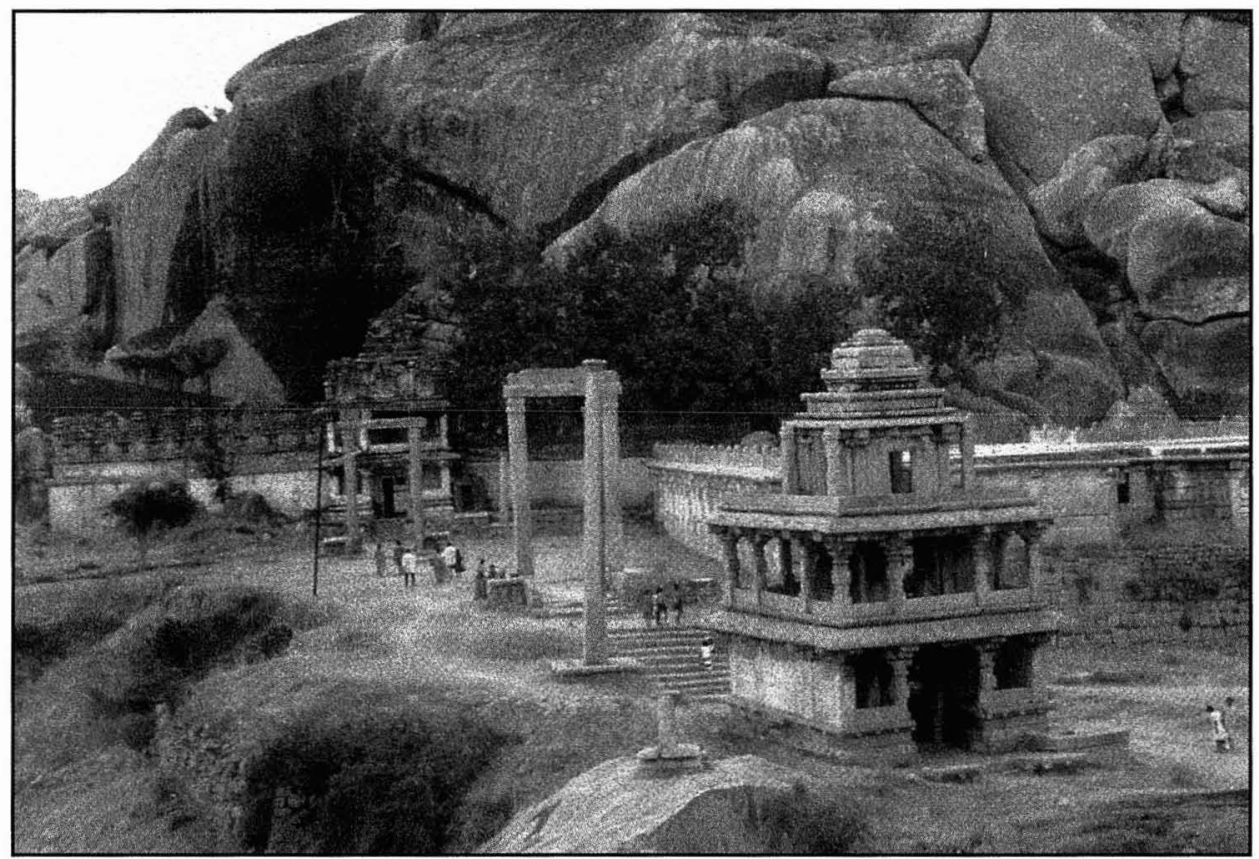

Fig. 5. Royal display area of the inner fort at Chitradurga Fort. The gateway in the right foreground leads to Hidimbeswara temple, one of the oldest temples on the hill. A monolithic pillar and two swing frames lie between the entrance to this gateway and the Sampige Siddheshvara temple, which rests at the foot of the hill in the left background. View is to the south.

this poligar headquarters town as it existed at the beginning of the nineteenth century.

Major Towns - Site surveys of the 11 other major towns identified on the 18001801 Mysore Survey map of Chitradurga province suggest that, while they are large and complex sites, they differed in importance, population, area, fortification complexity, ease of communication, public architecture, siege storage capacity, and other dimensions from Chitradurga Fort. Although the fortified areas of such sites as Hosadurga and Kanakuppa (Fig. 1), are nearly as large as that of Chitradurga Fort, one would search in vain within their walls for the remains of anything that resembles the palaces, royal display areas, and combination of extra-regional architectural traditions that are distinctive of Chitradurga Fort. The absence of the material trappings of kingship is consistent with the subsidiary role ascribed to the major towns by inscriptions and other contemporaneous documents.

Nevertheless, the major towns were more similar to Chitradurga Fort and to each other than any of them were to the minor towns. Archaeological site surveys demonstrate that the major towns typically possessed as many as two to three fortification lines and a considerable investment in siege store facilities. While they lacked the well-endowed major temples that were one measure of the high status of Chitradurga Fort, they were rich and populous enough to support temples. At 


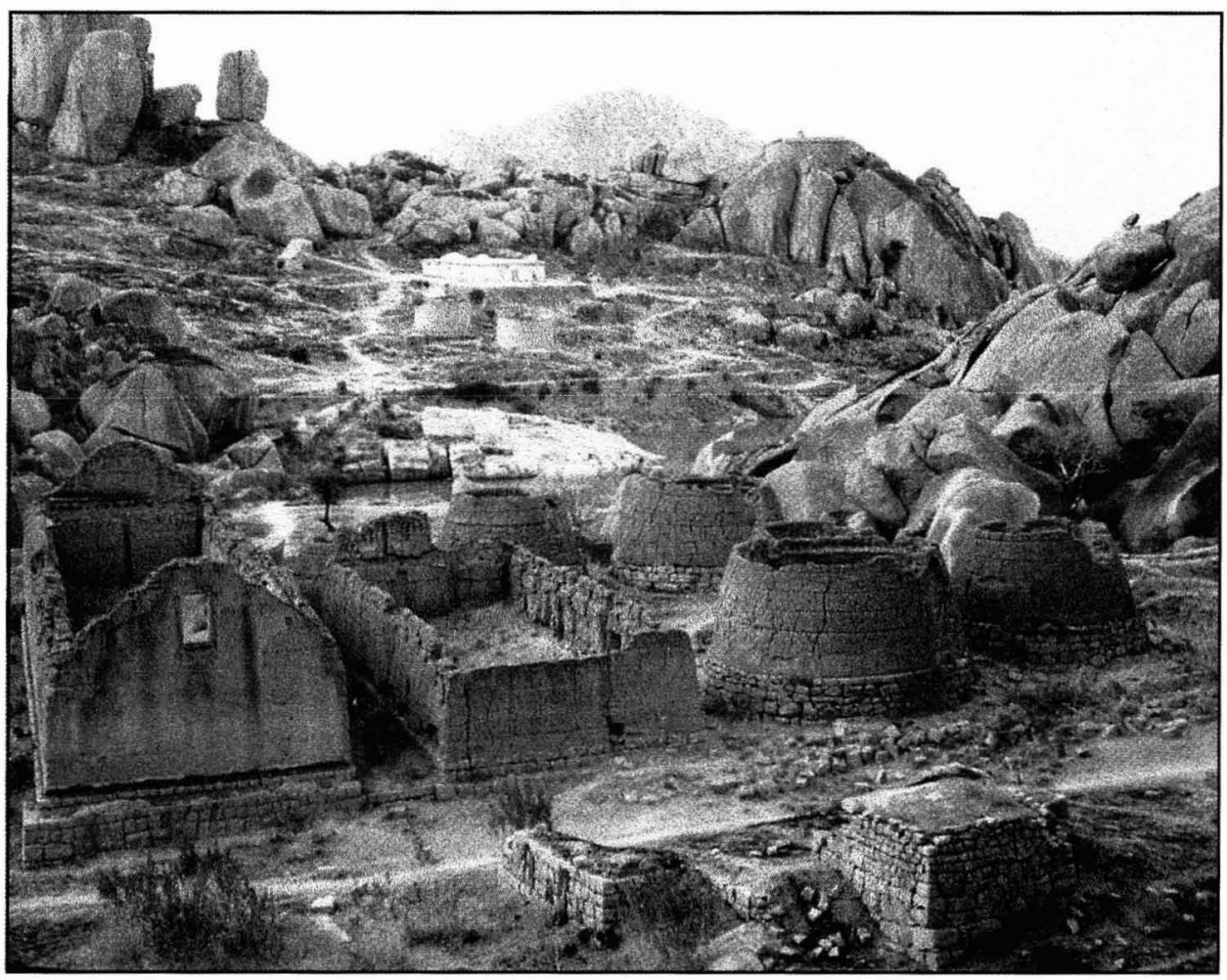

Fig. 6. Nayaka period granaries and storehouses in the Upper Palace area of Chitradurga Fort. View is to the northwest.

Kanakuppa and Hosadurga, both of which were abandoned more than a century ago, some temples continue to be used for worship today.

One striking fact revealed by our site survey is that roughly one-half of the major towns have not survived the past two centuries well. Colin Mackenzie (1803), for example, mapped substantial forts with well-built walls, bastions, and ditches at Tallak and Mayaconda in 1801. These defensive works have been so thoroughly recycled into modern buildings and shops that no visible evidence of their former existence can now be seen on the ground except for the ditches that formerly encircled the town walls.

Minor Towns and Villages - Like the major towns, all but three of the 65 minor towns identified on the Mysore Survey maps in Chitradurga province were fortified, but how they were fortified differed considerably from town to town. Simply put, the fortifications of minor towns share many stylistic elements with the major towns, but the combination of these elements and their expression in the design of minor town defenses were diverse. At Aimangala (Fig. 7c), for example, which is located on a gently rolling plain about halfway between Hiriyur and Chitradurga, the town walls define a $1.7-\mathrm{km}$ perimeter, which would have required a much larger garrison to defend than a small town could have 

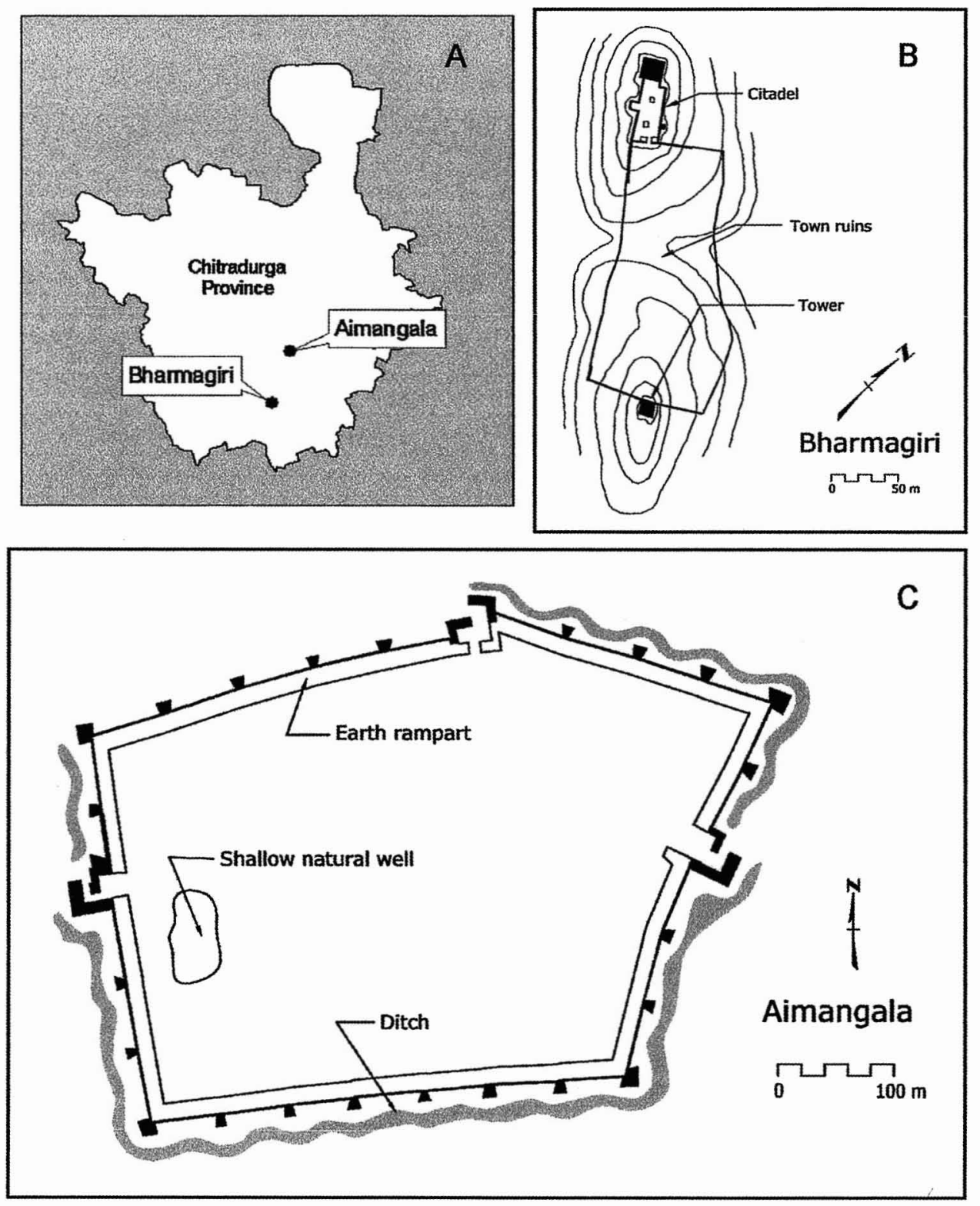

Fig. 7. Diversity of minor town defenses: A: locations of Aimangala and Bharmagiri in Chitradurga province; B: Bharmagiri plan (contour lines are approximate and intended only to give an impression of the topographical relationship between the parts of the town walls); C: Aimangala plan.

supported. The three bent entrances to Aimangala resemble hundreds of other South Indian town gateways of this period, but the battered curtain walls and bastions, which are trapezoidal in plan, are unique among the forts of the province. About $35 \mathrm{~km}$ to the south-southwest of Aimangala, the remains of Bharmagiri, another Nayaka period minor town, show a completely different expression, 
in which the builders crowned the crests of two adjacent hills with square towers and then built the town between walls on the saddle between the towers (Fig. $7 b$ ). While some of the diversity of these town defenses can undoubtedly be accounted for by their having been built at different times during the past few hundred years, much of it appears to reflect local decisions and designs. As was noted earlier in the discussion of the spatial patterning of pargana boundaries, lower level administrative institutions appear to have enjoyed considerable autonomy from the provincial ruling elites.

The 722 settlements that were identified as villages on the 1800-1801 Mysore Survey map also were quite variable. Although few villages are dclimited by fort symbols on this map, it is clear from site surveys, other Mysore Survey documents and maps, and from contemporary accounts (e.g., Buchanan 1807:304, 310) that most villages made at least some attempt to protect their families and property from marauders. The larger villages were typically surrounded by walls with towers in the angles and an outer perimeter of dense hedges of thorns; smaller communities often based their defense on thorn hedges and a single stone tower, or hude, in the middle of the village. The remains of mud and rubble village walls punctuated by relatively low and narrow gateways are the most enduring and obtrusive archaeological evidence of Nayaka habitation site locations identified in reconnaissance surveys.

In summary, Chitradurga Fort possesses many features that set it apart from the other towns of the region, and it would easily be identifiable as a principal place even if historical documentation were absent. Only the most important towns of the province were prepared to resist assault by an army, but, among these sites, only Chitradurga Fort shows the necessary investment of resources to withstand attack by a disciplined army with siege guns. The other major towns are less well fortified, their temples are less prosperous, and they lack architecture associated with royal display. All of these towns, however, are more similar to each other than they are to the minor towns of the region. The latter show highly variable plans, diverse defensive works, and locations that are often far removed from major communication routes. Villages were just as diverse as the minor towns, if not more so. Like contemporaneous maidan settlements elsewhere in Karnataka, villages were nucleated and designed to protect the persons and, if possible, the property of the inhabitants. The major factors that determined Nayaka habitation site locations appear to have been history, road proximity, water sources, arable land, and defense.

\section{CONCLUSION}

As the Chitradurga example demonstrates, Nayaka archaeology can be as much about archival research as about archaeology. Both are essential to the understanding of these turbulent centuries of early modern South Indian history. The Mysore poligars are interesting because they represent historically documented instances of the emergence of small states that strived for independence in a region that had been thrown into anarchy by the collapse of the larger state (Vijayanagara in this case), of which they had formerly been a part. A broad outline of the many political, economic, and social factors that played important roles in the rise and fall of the Mysore poligars is given by the historical record. How- 
ever, even after the documentary record has been thoroughly examined (and much remains to be done in this area, e.g., Desikachar 1977), important pieces of the picture would be missing if archaeological research were not available to provide the spatial and material contexts that are essential to a complete interpretation of these data.

By digitizing 200-year-old, large-scale maps of the Mysore kingdom, we have assembled a virtual archaeological site file of nearly 1000 Nayaka period site locations in Chitradurga province. Roughly 30,000 more locations in the Mysore kingdom have yet to be digitized. This represents a flood of fresh information, the accuracy of which we have only begun to confirm through field survey.

The Chitradurga data enable us to delineate several of the major spatial patterns of one Nayaka polity at the beginning of the nineteenth century. We emphasize gross economic and political patterns in this article because these aspects are readily identified through the integrated analysis of historical cartography and archaeological reconnaissance survey, which are the primary data we use here. Nevertheless, it is a work in progress. Many other aspects of the Chitradurga cultural landscape (e.g., climatic, geographical, and ritual landscapes) have yet to be examined.

The important themes that emerge from this analysis are the resilience of lower-level administrative structures in the parganas, and such enduring concerns as defense and communication. The distribution of major towns appears to reflect their role as trade and service centers for nearby small towns and villages, with Chitradurga Fort occupying the central nodal position for the entire province. This primarily economic interpretation of regional patterning is also supported by the tendency for minor towns to occasionally overtake and replace their closest major town. A further implication of the pattern is that the internal boundaries of the province may not delineate territories carved out of the region by the political and military might of competing poligar lineages. Rather, they may simply reflect the limits of contiguous, but otherwise largely self-contained service areas that were nominally controlled by local elites.

\section{ACKNOWLEDGMENTS}

This article is based on a paper presented at the $66^{\text {th }}$ Annual Meeting of the Society for American Archaeology, New Orleans, Louisiana, 18-22 April 2001. We gratefully acknowledge the generous research support of the American Institute of Indian Studies, the UIUC Research Board, and Intel Corporation. Jagadeesh C. and Shankar Athani, both of Chitradurga, and Venkata Naik of Mysore, made many contributions to every stage of the field research. The data used in this article are on file with the Karnataka Directorate of Archaeology and Museums and the UIUC Department of Anthropology.

\section{NOTES}

1. "Nayaka," with the first letter capitalized, refers to the early modern period of that name in South Indian history. As used here, "nayaka," in lower case, can mean a local military governor appointed by a higher king or a "little king" who traces the legitimacy of his rule to an ancestor who held such an office in the same headquarters town or general region. As Wilson $(1968: 372)$ explains, the meaning varied considerably across India. In the study region, it is sometimes used as a synonym for poligar. 
2. The name Chitradurga refers both to the province and its main city. To minimize possible confusion, our use of the name applies only to the province; by the term Chitradurga Fort we mean the city and fort that form the headquarters town of that province.

3. In Anglo-Indian usage, a chela battalion was a military unit comprised of slaves, prisoners, and converts (Yule and Burnell 1903:190). James Scurry's (1831) account of his experiences as a slave-soldier in one of Mysore's chela battalions gives a first-hand account of the brutal treatment these soldiers received. Scurry's book also includes several chapters on the years his battalion was assigned to Chitradurga Fort.

4. Our monograph on Chitradurga Fort, which is in preparation, will be the first major intrasite spatial study to incorporate these data.

5. Thiessen polygons are defined around points in a plane by connecting lines drawn so that they lie halfway between each point and its neighbors. The resulting polygons delineate "service areas" or "areas of influence" for each point (DeMers 2000:305-307) based simply on the implicit assumption that interaction with a given point increases with one's proximity to that point. The use of Thiessen polygons in archaeology has had a somewhat speckled past. First applied in archaeology in the 1960s and 1970s, critics took the concept to task for not considering significant social and geographical factors known to be at work in human interactions (e.g., Haselgrove 1986). The recent availability of powerful desktop GIS software applications, which typically include tools to generate Thiessen polygons, encourage archaeologists to reconsider the analytical value of this and similar tools, such as cost surface analysis, as estimates of spatial interaction (Wheatley and Gillings 2002:151-159). The data needed for a cost surface analysis of the spatial relationships between parganas are unavailable.

6. The town pairs include Jagalur, which replaced Kanakuppa; Challakere, which replaced Dodderi; and Davangere, which replaced Harihar.

7. It is also possible that the 1799-1808 Mysore Survey maps are biased against sites that were located far off the roads. Future field reconnaissance survey in Chitradurga District will check this possibility.

\section{REFERENCES CITED}

AIYAR, R. S.

1991 History of the Nayaks of Madura. Reprint of 1924 edition. New Delhi: Asian Educational Services.

BARCLAY, R.

1802 Report on the fort of Chittledroog. British Library, Oriental and India Office Collections, Board of Control, IOR/F/4/201/4575.

BOWRING, L. B.

1899 Haidar Ali and Tipu Sultan and the Struggle with the Musalmán Povers of the South. Oxford: Clarendon Press.

Brittlebank, K.

1997 Tipu Sultan's Search for Legitimacy: Islam and Kingship in a Hindu Domain. Delhi: Oxford University Press.

BUCHANAN, F.

1807 A Journey from Madras through the Countries of Mysore, Canara, and Malabar. 3 vols. London.

Chitnis, K. N.

1974 Keladi Polity. Dharwar: Karnatak University.

2000 The Nawabs of Savanur. New Delhi: Atlantic.

DELOCHE, J.

2000 Scnji Ville Fortifiée du Pays Tamoul. Paris: Ecole Française d’Extrême-Orient.

DeMers, M. N.

2000 Fundamentals of Geographic Information Systems. 2nd ed. New York: John Wiley.

DESIKACHAR, S. V.

1977 Archival wealth and post-Vijayanagara Karnataka history. The Indian Archives 26(1-2): $1-18$.

Dirks, N. B.

1982 The pasts of a Palaiyakarar: The ethnohistory of a South Indian little king. Journal of Asian Studies $41: 655-683$ 
1994 The Hollow, Crown: Ethnohistory of an Indian Kingdom. 2nd ed. Ann Arbor: University of Michigan Press.

DUA, J. C.

1996 Palegars of South India: Forms and Contents of their Resistance in Ceded Districts. New Delhi: Reliance Publishing House.

EDNEY, M. H.

1997 Mapping an Empire: The Geographical Construction of British India, 1765-1843. Chicago: University of Chicago Press.

Fox, R. G.

1971 Kin, Clan, Raja, and Rule: State-Hinterland Relations in Preindustrial India. Berkeley: University of California Press.

GORDON, S.

1994 Kinship and pargana in eighteenth-century Khandesh, in Marathas, Marauders, and State Formation in Eighteenth-Century India: 122-150, by S. Gordon. Delhi: Oxford University Press.

Green, C.

1846 Memorandum on public works in Mysore, in Selections from the Records of the Mysore Commissioner's Office: 1-18 (paginated separately), by Office of the Commissioner. Bangalore: Mysore Government Press.

Haselgrove, C. C.

1986 Central places in British Iron Age studies: A review and some problems, in Central Places, Archaeology and History: 3-12, ed. E. Grant. Sheffield, UK: University of Sheffield.

Hayavadana Rao, C.

1930 Mysore Gazetteer. New ed. 5 vols. Bangalore: Government Press.

Krishna, M. H.

1993a Annual Report of the Directorate of Archacology and Museums in Karnataka for the Year 1929. Mysore: Karnataka Directorate of Archaeology and Museums.

1993b Annual Report of the Directorate of Archacology and Museums in Karnataka for the Year 1930. Mysore: Karnataka Directorate of Archaeology and Museums.

LEWIS, R. B.

1997 Forts of the Poligar chiefdoms, Chitradurga District, Karnataka, India. Paper presented at the 26th Annual Conference on South Asia, 16-19 October 1997, Madison, WI.

2000 The Mysore parganas as expressions of regional identities, A.D. 1800-1808. Paper presented at the 29th Annual Conference on South Asia, Madison, WI.

2001 The Mysore kingdom at A.D. 1800: An archaeological analysis of the Mysore Survey of Colin Mackenzie. Paper presented at the 16th International Conference on South Asian Archaeology, 2-6 July 2001, Paris, France.

MackenZie, C.

1803 Remarks on the forts on the northern frontier of Mysore in 1800 and 1801 (extracted from the papers of the Mysore Survey), prepared by Capt. Colin Mackenzie of the Engineers and Superintendent Mysore, Fort St. George, 12 January 1803. University of Southampton, Hartley Library, Wellington Papers 3/3/100.

Michell, G.

1995 Architecture and Art of Southern India: Vijayanagara and the Successor States. The New Cambridge History of India 1:6. Cambridge: Cambridge University Press.

Nagarajan, K. G., and A. Sundara

1985 M. H. Krishna: His Life, Work and Contribution to Karnataka Archacology. Mysore: Karnataka Directorate of Archaeology and Museums.

Narayana Rao, V., D. Shulman, and S. Subrahmanyam

1992 Symbols of Substance: Court and State in Nayaka Period Tamil Nadu. Delhi: Oxford University Press.

OTA, N.

1999 Beda nayaka and their historical narratives in Karnataka during the post-Vijayanagara period, in Kingship in Indian History: 163-194, ed. N. Karashima. Japanese Studies on South Asia No. 2. New Delhi: Manohar. 
Patil, C. S.

1999 Karnataka Kotegalu [Forts of Karnataka]. Hampi: Kannada University.

Phillimore, R. H.

1945- Historical Records of the Survey of India. 3 vols. Dehra Dun: Survey of India. 1958

Puttanna, M. S

1924 Chitradurgada Palcyagararu [Chitradurga Poligars]. Bangalore.

RAJAYYAN, K.

1974 Rise and Fall of the Poligars of Tamilnadu. Madras: University of Madras.

Ramachandra RaO, P. B.

1943 The Poligars of Mysore and Their Civilization. Teppakulam: Palaniappa Bros.

RichaRds, J. F.

1993 The Mughal Empire. The New Cambridge History of India, vol. 1, pt. 5. Cambridge: Cambridge University Press.

RICE, B. L.

1897 Mysore: A Gazetteer Compiled for Government. Revised ed. 2 vols. London: Archibald Constable and Company.

1903 Inscriptions in the Chitaldroog District. Epigraphia Carnatica, vol. 11. Bangalore: Mysore Government Central Press.

Rовв, P.

1998 Completing "our stock of geography," or an object "still more sublime": Colin Mackenzie's survey of Mysore, 1799-1810. Journal of the Royal Asiatic Society, series 3, $8: 181-206$

SAletore, R. N.

1940 The Conquest of Citradurga by Hyder Ali. Quarterly Journal of the Mythic Society $29: 171-188$.

SATHYAN, B. N., ED.

1967 Mysore State Gazetteer: Chitradurga District. Bangalore: Government Press.

SCURRY, J.

1831 The Captivity, Sufferings, and Escape of James Scurry, Who was Detained a Prisoner during Ten Years, in the Dominions of Hyder Ali and Tippoo Saib. London: Henry Fisher.

SeTtar, S., ED.

1976 Archaeological Survey of Mysore, Annual Reports: 1906-1909, A Study. Aids to Research Series No. 1, vol. 2. Dharwar: Karnatak University.

SRikanta Sastri, S.

1928 Capitulation of Chitradurga. Quarterly Journal of the Mythic Society 18:145-154.

SRIKANTAYa, S

1941 Chitaldrug. Quarterly Journal of the Mythic Society 31:339-356.

SRINIVAS, M. V.

1991 Hullur Srinivasa Jois, in Historiography of Karnataka: 231-235, ed. S. U. Kamath. Bangalore: The Mythic Society.

STEIN, B

1985 State formation and economy reconsidered. Modern Asian Studies 19:387-413.

SUJATHA, H. S.

1991 M. S. Puttanna and his contributions to the history and culture of Karnataka, in Historiography of Karnataka: 235-242, ed S. U. Kamath. Bangalore: The Mythic Society.

SWAMinathan, K. D.

1957 The Nayakas of Ikkeri. Madras: P. Varadachary.

VRIDDHAGIRISAN, V.

1995 The Nayaks of Tanjore. Reprint of 1942 ed. New Delhi: Asian Educational Services.

WAGONER, P. B.

2001 Kannada Kalla Upparige (Stone Palace): Multistoried entrance pavilions in pre- and early Vijayangara architecture. Ars Oricntalis 31:167-183. 
Wheatley, D., and M. Gillings

2002 Spatial Teclunology and Archacology: The Archaeological Applications of GIS. London: Taylor and Francis.

WHEELER, R.E.M.

1948 Brahmagiri and Chandravalli 1947: Megalithic and other cultures in Mysore State. Ancient India $4: 180-310$.

WILKS, M.

1989 Historical Sketches of the South of India in an Attempt to Trace the History of Mysore. 2 vols. Reprint of 1930 ed.; originally published in 1810. New Delhi: Asian Educational Services.

WILSON, H. H.

1968 A Glossary of Judicial and Revenue Terms, and of Useful Words occurring in Official Documents relating to the Administration of the Government of British India. 2nd ed. Delhi: Munshiram Manoharlal.

Yule, H., and A. C. Burnell

1903 Hobson-Jobson: A Glossary of Colloquial Anglo-Indian Words and Phrases, and of Kindred Terms, Etymological, Historical, Geographical and Discursive. London: John Murray.

\begin{abstract}
South Indian historical accounts, inscriptions, and literature describe many attempts at state formation and political independence by local elites between the collapse of Vijayanagara control of its heartland in the sixteenth century and the eighteenthcentury rise of British hegemony in the south. Most of these elites, known variously as "little kings," nayakas, and poligars, did not survive long in the political turmoil of the era. Those that did endure into the early nineteenth century were soon marginalized or removed from power by East India Company policies and direct military intervention. Archaeological site surveys, guided by contemporaneous East India Company manuscript maps, fort inventories, building plans, and other records, enable researchers to reconstruct and interpret major spatial patterns of the cultural landscapes of these small polities. This approach, which the authors are currently applying in their investigations of the Mysore kingdom, yields a fresh perspective of South Indian little kings and chiefs that complements the work of historians and contributes significantly to the understanding of the nature of these polities. This article describes a case study of the major spatial patterns of the Chitradurga poligars of central Karnataka, as they were in the late eighteenth and early nineteenth centuries. The results provide a fresh perspective on this poligar province and illustrate the significant interpretative value of contemporaneous colonial documents for archaeological site survey and spatial analyses in India. KeYwords: India, Mysore, Nayaka period, poligars, spatial analysis, colonial archives, archaeological site survey.
\end{abstract}

